Article

\title{
Foliar Aspersion of Salicylic Acid Improves Nutraceutical Quality and Fruit Yield in Tomato
}

\author{
Oscar Sariñana-Aldaco ${ }^{1}\left(\mathbb{D}\right.$, Esteban Sánchez-Chávez ${ }^{2}$, Enrique Troyo-Diéguez ${ }^{3, *} \mathbb{*}$, \\ Luis Mario Tapia-Vargas ${ }^{4}$, Juan Carlos Díaz-Pérez ${ }^{5}\left[\right.$ and Pablo Preciado-Rangel ${ }^{1, *(1)}$
}

1 Technological Institute of Torreón (ITT), National Technologic of Mexico, Carr. Torreón-San Pedro Km 7.5, Torreón, COA 27170, Mexico; oscarsarinana390@gmail.com

2 Center for Research in Food and Development (CIAD) A.C., Avenida Cuarta Sur No. 3820, Fraccionamiento Vencedores del Desierto, Delicias, CUU 33089, Mexico; esteban@ciad.mx

3 Center for Biological Research of Northwest México (CIBNOR S.C.), Instituto Politécnico Nacional 195, Colonia Playa Palo de Santa Rita Sur, La Paz, B.C.S. 23096, Mexico

4 Uruapan Experimental Field, National Institute of Forestry, Agricultural and Livestock Research (INIFAP), Av. Latinoamericana 1101, Col. Revolución, Uruapan, Mich 60150, Mexico; tapia.luismario@inifap.gob.mx

5 College of Agricultural and Environmental Sciences, University of Georgia, Athens, GA 30602, USA; jcdiaz@uga.edu

* Correspondence: etroyo04@cibnor.mx (E.T.-D.); ppreciador@yahoo.com.mx (P.P.-R.); Tel.: +52-612-1238484 (ext. 3442) (E.T.-D.); +52-871-7893776 (P.P.-R.)

Received: 18 September 2020; Accepted: 9 October 2020; Published: 19 October 2020

check for updates

\begin{abstract}
The use of elicitors or biostimulants such as salicylic acid (SA) is an emerging novel practice to improve the yield and quality of crops since it plays an important role in the regulation of various physiological and metabolic processes. The objective of this research was to study the effect of the foliar application of SA on the nutraceutical quality and yield of tomato fruits. A completely randomized experimental design with 10 repetitions was used. SA was applied at five doses (0.025 mM, $0.05 \mathrm{mM}, 0.075 \mathrm{mM}, 0.1 \mathrm{mM}$, and $0.125 \mathrm{mM}$ ) every 15 days through foliar sprays after transplantation, accumulating seven applications through the cycle. The response variables were yield (total fruit weight per plant), fruit parameters (weight, diameter, firmness, and total soluble solids), percentage of weight loss, and nutraceutical quality. The obtained results suggest that the foliar spraying of SA improves the yield and biosynthesis of phytochemical compounds in tomato fruits, compared to control plants. According to the results, it is advisable to use the dose of $0.125 \mathrm{mM}$ of SA since it has a higher content of bioactive compounds without compromising yield.
\end{abstract}

Keywords: Solanum lycopersicum L.; phytochemical compounds; weight loss; biostimulants

\section{Introduction}

Tomato (Solanum lycopersicum L.), is the most consumed and cultivated horticultural species in the world [1] and its fruit has a large number of phytochemical compounds that can improve health [2]. Therefore, studies to increase yield and nutraceutical quality are desirable; in this sense, an agronomic biotechnology that allows us to stimulate yield and increase the biosynthesis of phytochemical compounds in the plants is the use of elicitors [3]. Salicylic acid (SA) is a growth regulator [4] that improves yield [5] and prolongs the shelf life of fruits [6]. In addition, SA can regulate the levels of reactive oxygen species in plants by controlling the activity of protective enzymes and avoiding or eliminating plant cell damage caused by oxygen stress [7]. The above is due to increases in the activity of the enzymes phenylalanine ammonium lyase (PAL) [8] and peroxidases (POD) [9], which improve the biosynthesis of antioxidant compounds in the plant [10]. Antioxidant compounds have a chemical structure that prevents the formation of free radicals and can prevent diseases caused 
by oxidative stress [11]. Among the most important antioxidants are phenolic compounds, vitamins, and carotenes [12] which provide anti-inflammatory, anticancer, antiviral, and antiallergic benefits [13]. From this perspective, the objective of this research was to determine the effect of the foliar application of SA on the yield and nutraceutical quality of tomato fruits under soilless conditions.

\section{Materials and Methods}

The study was carried out in a greenhouse covered with a 720-caliber high density polyethylene film and a semi-automatic cooling system (wet wall and extractors) (Figure 1), located at the Technological Institute of Torreón, México $\left(24^{\circ} 30^{\prime}\right.$ and $27^{\circ} \mathrm{NL}, 102^{\circ} 00^{\prime}$ and $104^{\circ} 40^{\prime} \mathrm{WL}$, at an altitude of $1120 \mathrm{~m}$ ).
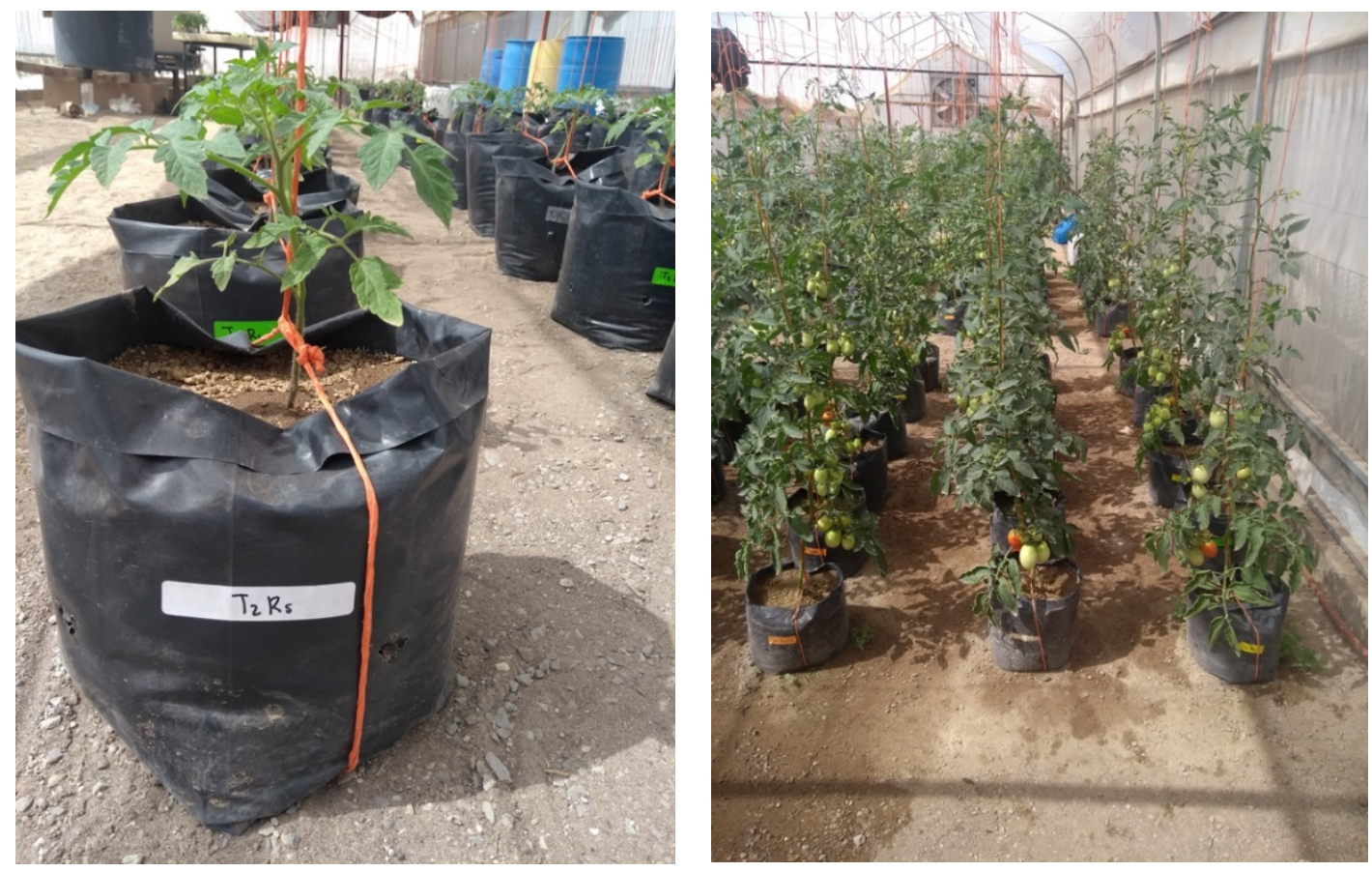

Figure 1. Sahel hybrid tomato plants under greenhouse conditions; Technological Institute of Torreón, México.

\subsection{Experimental Design}

A completely randomized experimental design was used with five doses of SA $(0.025 \mathrm{mM}$, $0.05 \mathrm{mM}, 0.075 \mathrm{mM}, 0.1 \mathrm{mM}$, and $0.125 \mathrm{mM})$ and a control. Similar varying SA supply $(0 \mathrm{mM}, 0.1 \mathrm{mM}$, $0.5 \mathrm{mM}$, and $1.0 \mathrm{mM}$ ) on growth, mineral uptake, chlorophyll, carotenoid concentrations, and other variables of crops have been previously tested and validated [14]. The effect of exogenous SA on growth is dependent on concentration and plant species; usually, SA at relatively low concentrations (less than $100 \mu \mathrm{M}$ ) enhances plant growth [15]. Accordingly, the selection of the applied doses was made considering the results and suggestions of previous studies, aiming to find the doses that may lead us to improve the nutraceutical fruit quality without compromising the yield of tomato [4-7].

Each dose had 10 repetitions, accomplishing 60 experimental units (EU); one EU consisted in one plant grown in a plastic pot, establishing ten plants per treatment.

\subsection{Plant Material and Experimental Conditions}

Sahel hybrid tomato seedlings with six true leaves were transplanted into black polyethylene plastic pots of 500 caliber of $15 \mathrm{~kg}$ capacity, which contained river sand and perlite (80:20) as the substrate. The river sand was washed and disinfected with a $5 \%$ sodium hypochlorite solution. The pots were placed in a double row, in a staggered arrangement, so that a density of four plants 
per square meter was obtained. A drip irrigation system was used to provide three irrigations per day; each plant per day received $0.6 \mathrm{~L}$ from transplant to the beginning of flowering and $2.5 \mathrm{~L}$ to $3.5 \mathrm{~L}$ from flowering to harvest. The plants were guided to a stem and for support were staked with raffia attached to the upper part of the greenhouse structure. The activity of pollinating agents was emulated to maintain production using an electric brush at the beginning of flowering.

The nutrient solution for the plant was prepared according to Steiner [16]. The $\mathrm{pH}$ and electrical conductivity were maintained at $5.5 \mathrm{dS} \mathrm{m}^{-1}$ and $2.0 \mathrm{dS} \mathrm{m}^{-1}$, respectively. The response variables were yield and its components, percentage of weight loss, and the nutraceutical quality of the fruit.

The experimental doses were applied every 15 days through foliar spray from the transplant, accumulating seven applications of SA through the life cycle. Pure SA (2-hydroxybenzoic acid, Sigma Chemical Co. St. Louis, MO, USA) was initially dissolved in $100 \mathrm{~mL}$ of dimethylsulfoxide (pH 6.0-6.5) prepared with distilled water containing $0.02 \%$ Tween 20.

SA foliar sprays were carried out between 8:00 a.m. and 10:00 a.m. with a manual sprinkler. In order to avoid spraying neighbor plants and a possible overlapping of treatments, a flexible plastic barrier was used to isolate the application space.

\subsection{Yield and Weight Loss of Fruits}

For yield quantification, ten fruits per plant per repetition of each treatment were harvested from the first to the fifth cluster when the fruits evidenced an intense red color. For estimating the fruit weight loss, a sample of 10 fruits was collected from the last bunch; the fruits were exposed to laboratory conditions, where the weight loss was taken seven days after harvest on a predefined scale (bapred-3 brand Rhino). The difference was calculated with respect to the initial weight, registering the data as percentage, according to the following expression:

$$
\mathrm{WL}(\%)=(\mathrm{IW}-\mathrm{FW}) / \mathrm{IW}
$$

where, WL: Weight Loss; IW: Initial weight; FW: Final weight

\subsection{Biophysical Fruit Quality and Firmness}

The biophysical fruit quality was evaluated in three fruits taken at random from each cluster, from each repetition of the treatments, measuring the average weight of the fruit, the polar and equatorial diameter, the firmness of the fruit, weight loss, and total soluble solids.

Firmness was measured with a penetrometer (Fruit Hardness Tester FHT200, Extech ${ }^{\circledR}$, Hsinchu, Taiwan), with an $8 \mathrm{mM}$ diameter strut. The readings were taken in the central part of the fruit and an average was obtained, and the results were expressed in Newton units $(\mathrm{N})$.

\subsection{Total Soluble Solids, Total Phenols, Flavonoids and Antioxidant Capacity}

The total soluble solids (TSS) were measured in ${ }^{\circ}$ Brix; for this purpose, a drop of juice was extracted from the fruit and the reading was taken in a manual refractometer from 0 to $32 \%$ (Master- $\alpha$ 2311, Atago ${ }^{\circledR}$, Tokyo, Japan).

For nutraceutical determinations, fruits from the last harvested bunch were used, which, at harvest time, were placed in a cooler to preserve their properties, then they were taken to a laboratory, where they were crushed and freeze-dried. For vitamin C, samples of the fruits were taken under the same conditions and the determination was made fresh.

For the nutraceutical quality assessment, total phenols were measured by means of colorimetry using the Folin-Ciocalteau method [17]; for this purpose, $5 \mathrm{~mL}$ of $80 \%$ methanol were added to a $0.5 \mathrm{~g}$ lyophilized sample to extract the compounds. A $750 \mu \mathrm{L}$ solution of $2 \% \mathrm{Na}_{2} \mathrm{CO}_{3}$ was added in a test tube, adding $250 \mu \mathrm{L}$ of $50 \%$ Folin-Ciocalteau reagent, and a volume of $1375 \mu \mathrm{L}$ of deionized $\mathrm{H}_{2} \mathrm{O}$ plus $250 \mu \mathrm{L}$ of the sample extract. The absorbance was measured at $725 \mathrm{~nm}$ by spectrophotometry. The results of total phenols were expressed in $\mathrm{mg}$ of gallic acid g ${ }^{-1}$ of dry weight (mg GA g $\left.{ }^{-1} \mathrm{DW}\right)$. 
The total flavonoids were analyzed according to the method of Zhishen et al. [18]. Compounds were extracted with methanol. A quantity of $0.5 \mathrm{~g}$ of sample lyophilized was homogenized with $5 \mathrm{~mL}$ of $80 \%$ methanol. It was centrifuged at $4000 \mathrm{rpm}$ for $10 \mathrm{~min}$ at $4{ }^{\circ} \mathrm{C}$. In order to get the desired mix, $250 \mu \mathrm{L}$ of the aliquot was placed in a test tube, followed by the addition of $75 \mu \mathrm{L}$ of $\mathrm{NaNO}_{2}$ and vortexed. After five minutes $150 \mu \mathrm{L}$ of $\mathrm{AlCl}_{3}$ was added; then, a volume of $500 \mu \mathrm{L}$ of $\mathrm{NaOH}$ was added, plus a volume of $2025 \mathrm{~mL}$ of $\mathrm{H}_{2} \mathrm{O}$. The absorbance was immediately measured by spectrophotometry at $510 \mathrm{~nm}$. Flavonoids were quantified based on a standard catechin curve, based on dry weight (mg CE g $\left.{ }^{-1} \mathrm{DW}\right)$.

The antioxidant capacity was determined by the method proposed by Hsu et al. [19], using the free radical 1,1-diphenyl-2-picryl-hydracil (DPPH), which has an absorption maximum of $517 \mathrm{~nm}$. The extract was obtained by macerating $1 \mathrm{~g}$ of lyophilized tomato sample in $5 \mathrm{~mL}$ of $80 \%$ methanol, then centrifuging it at $6000 \mathrm{rpm}$ for $10 \mathrm{~min}$ at a temperature of $4{ }^{\circ} \mathrm{C}$, followed by extracting $0.5 \mathrm{~mL}$ of the resulting supernatant. Finally, $2.5 \mathrm{~mL}$ of $0.1 \mathrm{mM}$ DPPH solution were mixed, which was incubated for $60 \mathrm{~min}$ in the dark and cold. The absorbance was measured in an ultraviolet-visible spectrophotometer at $517 \mathrm{~nm}$. The white was measured using $0.5 \mathrm{~mL}$ of $80 \%$ methanol and $2.5 \mathrm{~mL}$ of $0.1 \mathrm{mM} \mathrm{DPPH}$ solution. The results of the DPPH test were obtained with the following equation:

$$
\begin{gathered}
\text { Inhibition percentage }=(1-X) \times 100 \\
\qquad X=A_{517} \text { samples/A517 white }
\end{gathered}
$$

where results are expressed as inhibition percentage.

\subsection{Lycopene Extraction and Vitamin C Content}

The lycopene extraction was carried out according to Fish et al. [20], with some modifications. Approximately $1 \mathrm{~g}$ sample (without seeds) was placed in $50 \mathrm{~mL}$ aluminum-covered test tubes while on ice. An extraction solution $(39 \mathrm{~mL})$ of hexane, $0.05 \%(w / v)$ butylated hydroxytoluene (BHT) in acetone, and 95\% ethanol in a 1:1:1 ratio was added to the tubes and stirred for $10 \mathrm{~min}$ at $180 \mathrm{rpm}$. Six $\mathrm{mL}$ of cold distilled water was added to each tube and stirred for an additional five minutes for better separation of polar and nonpolar compounds. The tubes were then removed from shaking and left for $15 \mathrm{~min}$ at room temperature to separate into polar and non-polar layers. The supernatant was placed in new $15 \mathrm{~mL}$ aluminum covered test tubes and kept at $-80^{\circ} \mathrm{C}$ for further experiments. The absorbance of the supernatant (hexane layer) containing lycopene was read three times using the spectrophotometer at a wavelength of $503 \mathrm{~nm}$. Absolute hexane was used as a blank.

The amount of lycopene in the tissues were estimated with the following expression:

$$
\text { Lycopene }\left(\mathrm{mg} \mathrm{kg}^{-1} \mathrm{DW}\right)=(\mathrm{x} / \mathrm{y}) \times \mathrm{A}_{503} \times 3.12
$$

where, DW is dry weight, $x$ is the amount of hexane $(\mathrm{mL}), y$ is the weight of the sample, $A_{503}$ is the absorbance at $503 \mathrm{~nm}$, and 3.12 the extinction coefficient.

The content of vitamin $C$ was determined by the titration method based on fresh weight (FW) [21]. Fresh fruit samples of $10 \mathrm{~g}$ were taken, crushed together with $10 \mathrm{~mL}$ of $2 \%$ hydrochloric acid, filtered, and made up to $100 \mathrm{~mL}$ with distilled water in an Erlenmeyer flask. A volume of $10 \mathrm{~mL}$ of the dilute was titrated with 2.6 dichlorophenolindophenol $\left(1 \times 10^{-3} \mathrm{~N}\right)$ and the vitamin $\mathrm{C}$ content was determined with the following equation:

$$
\text { Vit } C(\mathrm{mg} \text { per } 100 \mathrm{~g} \mathrm{FW})=\frac{(\mathrm{mL} \text { of } 2.6 \text { diclorofenolindofenol })(0.088)(\text { total volume })(100)}{(\text { volume of aliquote })(\text { weight of sample })}
$$




\subsection{Statistical Analysis}

The results obtained were analyzed by analysis of variance and means comparison with the Tukey test $(p \leq 0.05)$ using the statistical package SAS (Statistical Analysis System Institute) version 9.3 [22]. The normality of data for each response variable was verified with the Kolmogorov-Smirnov Test; the data of the antioxidant capacity and weight loss variables (both expressed as a percentage) were normalized applying the arcsine and square root transformation [23].

\section{Results}

\subsection{Yield}

The SA foliar sprays at $0.05 \mathrm{mM}$ increased the yield in $0.43 \mathrm{~kg}$ per plant, compared to the control (Table 1), responding with a higher weight and number of fruits per plant; accordingly, previous studies reported that SA increases the number of flowers and fruits per plant, thus ensuring a higher yield [24].

Table 1. Tomato yield components as affected by salicylic acid (SA) foliar sprays.

\begin{tabular}{cccccc}
\hline (SA) (mM) & Fruit Number & Polar Diameter (mm) & $\begin{array}{c}\text { Equatorial } \\
\text { Diameter (mm) }\end{array}$ & Fruit Weight (g) & Yield (kg plant $\left.\mathbf{~}^{-1}\right)$ \\
\hline 0.00 & $21.6 \pm 1.6 \mathrm{~b}^{*}$ & $56.70 \pm 8.5 \mathrm{c}^{*}$ & $41.9 \pm 6.6 \mathrm{~b}^{*}$ & $100.7 \pm 9.6^{\mathrm{NS}}$ & $2.17 \pm 0.1 \mathrm{~b}^{*}$ \\
0.025 & $23.8 \pm 2.7 \mathrm{ab}$ & $61.20 \pm 3.3 \mathrm{abc}$ & $47.4 \pm 4.1 \mathrm{a}$ & $108.3 \pm 9.06$ & $2.57 \pm 0.3 \mathrm{a}$ \\
0.05 & $23.8 \pm 1.9 \mathrm{ab}$ & $67.07 \pm 4.6 \mathrm{a}$ & $45.6 \pm 4.2 \mathrm{ab}$ & $108.9 \pm 5.2$ & $2.60 \pm 0.3 \mathrm{a}$ \\
0.075 & $25.0 \pm 3.2 \mathrm{a}$ & $63.02 \pm 2.4 \mathrm{ab}$ & $47.5 \pm 0.9 \mathrm{a}$ & $104.3 \pm 6.1$ & $2.59 \pm 0.2 \mathrm{a}$ \\
0.100 & $22.5 \pm 2.8 \mathrm{ab}$ & $61.20 \pm 2.7 \mathrm{bc}$ & $44.7 \pm 2.6 \mathrm{ab}$ & $107.5 \pm 15.5$ & $2.44 \pm 0.6 \mathrm{a}$ \\
0.125 & $22.6 \pm 4.04 \mathrm{ab}$ & $63.50 \pm 2.9 \mathrm{ab}$ & $44.5 \pm 5.1 \mathrm{ab}$ & $108.8 \pm 10.3$ & $2.48 \pm 0.5 \mathrm{a}$ \\
\hline
\end{tabular}

Note. Values with same letters within a column are statistically similar. The significance level is represented by * at 0.05 according to Tukey, $p \leq 0.05$. NS: non-significant.

\subsection{Fruit Quality}

\subsubsection{Firmness and Weight Loss}

Among the quality parameters most appreciated by consumers is the firmness of fruits since possible mechanical damages severely affect the shelf life of fruits after harvest [25]. The SA dose of $0.125 \mathrm{mM}$ caused increases by $44.53 \%$ in the firmness and decreases by $60.38 \%$ in the weight loss of fruits, as compared to the control (Table 2).

Table 2. Tomato fruit biophysical quality and weight loss as affected by SA foliar sprays.

\begin{tabular}{cccc}
\hline SA (mM) & Firmness (N) & Weight Loss (\%) & TSS $\left({ }^{\circ}\right.$ Brix) \\
\hline 0.00 & $6.4 \pm 0.65 \mathrm{c}^{*}$ & $15.4 \pm 3.96 \mathrm{a} *$ & $6.0 \pm 0.37 \mathrm{c}^{*}$ \\
0.025 & $7.7 \pm 0.91 \mathrm{bc}$ & $15.0 \pm 1.37 \mathrm{a}$ & $6.6 \pm 0.40 \mathrm{abc}$ \\
0.05 & $8.5 \pm 0.99 \mathrm{ab}$ & $10.9 \pm 2.47 \mathrm{~b}$ & $6.2 \pm 0.44 \mathrm{bc}$ \\
0.075 & $8.7 \pm 1.07 \mathrm{ab}$ & $11.3 \pm 3.42 \mathrm{~b}$ & $7.1 \pm 0.51 \mathrm{a}$ \\
0.100 & $8.9 \pm 1.54 \mathrm{ab}$ & $9.4 \pm 2.08 \mathrm{c}$ & $7.0 \pm 0.83 \mathrm{a}$ \\
0.125 & $9.2 \pm 1.94 \mathrm{a}$ & $9.3 \pm 4.3 \mathrm{c}$ & $6.9 \pm 0.76 \mathrm{ab}$ \\
\hline
\end{tabular}

Note. Values with same letters within a column are statistically similar. The significance level is represented by * at 0.05 according to Tukey, $p \leq 0.05$. N: Newton.

The results are similar to those of a previous study, where it was reported that SA increased firmness by reducing the softening of fruits [26], delaying their ripening by avoiding the conversion of 1-aminocyclopropane-1-carboxylic acid (ACC) into ethylene which is responsible for cell senescence [27].

\subsubsection{Total Soluble Solids (TSS)}

Sugars are one of the most abundant components in fruits, accounting for most TSS [28]. Our results show that SA increased TSS of fruits in $1.1^{\circ}$ Brix with the dose $0.075 \mathrm{mM}$ (Table 2), which agree with 
results published by Baninaiem et al. [29], who reported significant increases of TSS in tomato fruits caused by SA.

\subsection{Nutraceutical Quality}

\subsubsection{Total Phenols and Flavonoids}

The obtained results indicate that the foliar spray with $0.125 \mathrm{mM}$ of SA promoted significant increases in phenolic compounds and total flavonoids, estimated, respectively, at 40.1 and $166.76 \%$ higher than the control (Table 3), being an effective biostimulant to maintain and enhance the phenolic compounds and antioxidants, desirable [30] for human health purposes [31].

Table 3. Nutraceutical quality of tomato fruits as affected by SA foliar sprays.

\begin{tabular}{|c|c|c|c|c|c|}
\hline SA (mM) & $\begin{array}{c}\text { Total Phenols } \\
\text { (mg GA g }{ }^{-1} \text { DW) }\end{array}$ & $\begin{array}{c}\text { Flavonoids } \\
\left(\mathrm{mg} \mathrm{CE} \mathrm{g}^{-1} \mathrm{DW}\right)\end{array}$ & $\begin{array}{l}\text { Antiox. Capacity } \\
\text { (\% Inhibition) }\end{array}$ & $\begin{array}{c}\text { Lycopene } \\
\left(\mathrm{mg} \mathrm{kg}^{-1} \mathrm{DW}\right)\end{array}$ & $\begin{array}{c}\text { Vitamin C } \\
\left(\mathrm{mg} 100 \mathrm{~g}^{-1} \text { FW }\right)\end{array}$ \\
\hline 0.00 & $18.9 \pm 3.3 b^{*}$ & $3.5 \pm 1.2 c^{*}$ & $69.01 \pm 2.1 b^{*}$ & $76.5 \pm 9.3 b^{*}$ & $19.6 \pm 1.6 c^{*}$ \\
\hline 0.025 & $20.8 \pm 0.8 \mathrm{ab}$ & $4.7 \pm 0.1 \mathrm{bc}$ & $72.04 \pm 3.2 \mathrm{~b}$ & $85.9 \pm 2.3 \mathrm{ab}$ & $20.5 \pm 1.6 b c$ \\
\hline 0.05 & $21.7 \pm 2.9 \mathrm{ab}$ & $5.3 \pm 1.3 b c$ & $76.01 \pm 1.3 \mathrm{ab}$ & $86.9 \pm 2.2 \mathrm{ab}$ & $23.7 \pm 1.7 \mathrm{ab}$ \\
\hline 0.075 & $23.2 \pm 2.9 \mathrm{ab}$ & $5.9 \pm 1.6 \mathrm{bc}$ & $80.58 \pm 7.4 \mathrm{a}$ & $89.3 \pm 1.9 a$ & $24.7 \pm 1.2 \mathrm{a}$ \\
\hline 0.100 & $24.6 \pm 4.2 \mathrm{a}$ & $6.8 \pm 1.6 \mathrm{ab}$ & $81.87 \pm 4.2 \mathrm{a}$ & $89.5 \pm 2.2 \mathrm{a}$ & $25.1 \pm 0.9 \mathrm{a}$ \\
\hline 0.125 & $26.4 \pm 4.2 \mathrm{a}$ & $9.4 \pm 2.1 \mathrm{a}$ & $82.92 \pm 2.1 \mathrm{a}$ & $89.5 \pm 2.2 \mathrm{a}$ & $25.9 \pm 0.2 \mathrm{a}$ \\
\hline
\end{tabular}

Note. Values with same letters within a column are statistically similar. The level of significance is represented by *, $p \leq 0.05$ according to Tukey Test. GA: gallic acid; CE: catechin equivalents.

\subsubsection{Antioxidant Capacity}

The results reflect a $20.15 \%$ inhibition increase for the antioxidant capacity in fruits treated with $0.125 \mathrm{mM}$ of SA, compared to the control (Table 3). These results are potentially beneficial for consumers [32] and are similar to those published previously [33], confirming an increase in the antioxidant capacity of tomato fruits treated with SA.

\subsubsection{Lycopene and Vitamin C}

Lycopene is the main carotenoid in tomato fruits, and it is considered that its intake can prevent various diseases [34]. The foliar applications of SA improved up to $16.92 \%$ the lycopene content, with the highest dose of SA, in relation to the control (Table 3). Similar increases of lycopene in tomato fruits with SA applications were reported elsewhere [29,35].

The foliar applications of SA increased the vitamin C content in tomato fruits up to $25.9 \mathrm{mg} 100 \mathrm{~g}^{-1}$ FW (31.55\% higher than control) (Table 3); as an antioxidant, vitamin C protects tissues from damage caused by free radicals [36]. It is expected to play fundamental roles in tomato plants as one of the most important antioxidants in their main defense system when facing different types of stress [37].

\subsubsection{Regression and Correlation Analysis}

The SA foliar sprays influence the nutraceutical parameters of tomato fruits in different intensities. Pearson linear correlations and regression models are shown in Table 4. The response variable Total Phenols (TP) reflected the strongest correlation with SA doses $(r=0.996)$, and Lycopene shows the weakest correlation $(r=0.833)$. The variable that responded with the highest unit increases was Flavonoids, reflecting six-units interval between the minimum and maximum values. On the other hand, Lycopene was the variable with the lowest amplitude of response to the doses of SA application, reflecting a difference of around 13 units between the maximum and minimum values. 
Table 4. Linear regression models $(y=a x+b)$ and correlation coefficients for five nutraceutical quality variables in response to SA foliar sprays.

\begin{tabular}{cccc}
\hline Response Variable (y) & $\begin{array}{c}\text { Linear Regression Model } \\
\text { (Axis x: SA in mM) }\end{array}$ & Correlation Coefficient $(\boldsymbol{r})$ & $\boldsymbol{p}$ (uncorr) \\
\hline Total Phenols (TP) & $\mathrm{TP}=57.6 \mathrm{SA}+19$ & 0.996 & 0.0001 \\
Flavonoids (Fl) & $\mathrm{Fl}=41.6 \mathrm{SA}+3.333$ & 0.958 & 0.0026 \\
Antiox. Capacity (AC) & $\mathrm{AC}=118.41 \mathrm{SA}+69.671$ & 0.976 & 0.0009 \\
Lycopene (Ly) & $\mathrm{Ly}=89.371 \mathrm{SA}+80.681$ & 0.833 & 0.0397 \\
Vitamin C (VitC) & $\mathrm{VitC}=52.914 \mathrm{SA}+19.943$ & 0.954 & 0.0031 \\
\hline
\end{tabular}

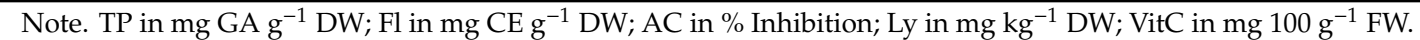
GA: gallic acid; $C E$ : catechin equivalents.

\section{Discussion}

The increases reached in yield can be derived from many processes in which SA is involved, including an increase in root growth [38]. Also, a greater absorption of nutrients, protein synthesis, division, and cell differentiation, associated to an increase in yield, have been observed [39]. Previous studies reported an increase in yield with SA low doses, but decreases with high doses [40], due to the oxidative stress that SA can cause and that the plant is unable to restore [41]. It is well known that plants respond to SA in different ways, but this response is dependent on the type of cultivar, environmental conditions, and SA concentration; in particular, tomato is a crop sensitive to this growth regulator [42]. In this study, toxicity levels were not reached, since all the plants treated with SA showed similar results. The highest SA doses $(0.1 \mathrm{mM}, 0.125 \mathrm{mM})$ improved the firmness, gaining a higher resistance, and therefore, a greater postharvest durability [43]; in this sense, fruits with less firmness evidence a higher weight loss during storage [44]. In contrast, a medium SA dose $(0.075 \mathrm{mM})$ promoted the highest value of TSS; in this context, the increase in TSS by SA is evidenced by the higher content of pigments and carbohydrates, which accumulate directly in the fruits, thus increasing the TSS [45]. A similar tendency was found for the phenolic compounds, as medium to high doses promoted the highest values. This finding is quite relevant for the nutraceutical quality, as SA increases the synthesis of antioxidant compounds like phenols, by stimulating a greater activity of phenylalanine ammonium lyase (PAL), responsible for the synthesis of this kind of compound [8,46].

The improvement of nutraceutical attributes through the application of biostimulants or elicitors, such as SA, is a response of plants to the stress caused by them, increasing the synthesis of phytochemical compounds [47]. Among the most relevant antioxidants produced by tomato, lycopene is considered a bioactive compound due to its importance related to the antioxidant capacity in vegetables, which is known to increase when secondary metabolism is activated, a condition caused by SA applications $[5,48]$. The observed increases of vitamin $C$ in tomato fruits treated with foliar applications of SA were similar to those reported previously by Hafeznia et al. [49], which is explained by a higher production of carbohydrates promoted by SA, being effective precursors for the synthesis of ascorbic acid [50]. Plants synthesize ascorbic acid mainly through the Smirnoff-Wheeler pathway, dominating in photosynthetic tissues; carbohydrates are its main intermediaries [51].

\section{Conclusions}

The foliar spraying of SA increased the yield and the biosynthesis of phytochemical compounds in tomato fruits, in relation to the control without application. In conclusion, to obtain a higher content of bioactive compounds without affecting the yield and commercial quality of tomato fruits, it is advisable to use a concentration of $0.125 \mathrm{mM}$ of SA. Finally, it should be noted that the use of SA is a viable and sustainable option to improve the yield and nutraceutical quality of horticultural crops.

Author Contributions: Conceptualization, P.P.-R. and E.S.-C.; methodology, O.S.-A. and P.P.-R.; software, J.C.D.-P.; validation, E.T.-D. and E.S.-C.; formal analysis, O.S.-A.; investigation, E.T.-D. and P.P.-R.; resources, J.C.D.-P.; data curation, L.M.T.-V.; writing—original draft preparation, P.P.-R.; writing—review and editing, E.T.-D. and P.P.-R.; 
visualization, L.M.T.-V.; supervision, P.P.-R. and E.T.-D.; project administration, O.S-A.; funding acquisition, P.P.-R. All authors have read and agreed to the published version of the manuscript.

Funding: This research was funded by the National Technologic of México (Tec Nacional de México)—Torreón Technological Institute, 2018-2019.

Acknowledgments: Many thanks are dully given to the technical staff of the Water and Soil Analysis Laboratory of ITT (Torreón, Coahuila), and the lab technicians of CIBNOR SC (La Paz, BCS) for their technical assistance. Administrative support was provided by the Graduate Studies and Research Division office of ITT (Coahuila).

Conflicts of Interest: The authors declare no conflict of interest; the authors also confirm that the funders had no role in the design of the study; in the collection, analyses, or interpretation of data; or in the decision to publish the results.

\section{References}

1. Kerketta, A.; Bahadur, V.; Rajesh, J. Performance of different tomato genotypes (Solanum lycopersicum L.) for growth, yield and quality traits under allahabad condition. J. Pharmacogn. Phytochem. 2018, 7, 1766-1769.

2. Talens, P.; Mora, L.; Bramley, P.M.; Fraser, P.D. Antioxidant compounds and their bioaccessibility in tomato fruit and puree obtained from a Detiolated-1 (DET-1) down-regulated genetically modified genotype. Food Chem. 2016, 213, 735-741. [CrossRef] [PubMed]

3. Miura, K.; Tada, Y. Regulation of water, salinity, and cold stress responses by salicylic acid. Front. Plant. Sci. 2014, 5, 4. [CrossRef] [PubMed]

4. Sánchez-Chávez, E.; Barrera-Tovar, R.; Muñoz-Márquez, E.; Ojeda-Barrios, D.; Anchondo-Nájera, Á. Efecto del ácido salicílico sobre biomasa, actividad fotosintética, contenido nutricional y productividad del chile jalapeño. Rev. Chapingo Ser. Hortic. 2011, 17, 63-68. [CrossRef]

5. Chen, Y.; Cui, J.; Li, G.; Yuan, M.; Zhang, Z.; Yuan, S.; Zhang, H. Effect of salicylic acid on the antioxidant system and photosystem II in wheat seedlings. Biologia Plant. 2016, 60, 139-147. [CrossRef]

6. Preciado-Rangel, P.; Reyes-Pérez, J.J.; Ramírez-Rodríguez, S.C.; Salas-Pérez, L.; Fortis-Hernández, M.; Murillo-Amador, B.; Troyo-Diéguez, E. Foliar aspersion of salicylic acid improves phenolic and flavonoid compounds, and also the fruit yield in cucumber (Cucumis sativus L.). Plants 2019, 8, 44. [CrossRef] [PubMed]

7. Jahan, M.S.; Wang, Y.; Shu, S.; Zhong, M.; Chen, Z.; Wu, J.; Guo, S. Exogenous salicylic acid increases the heat tolerance in tomato (Solanum lycopersicum L.) by enhancing photosynthesis efficiency and improving antioxidant defense system through scavenging of reactive oxygen species. Scient. Hortic. 2019, 247, 421-429. [CrossRef]

8. Hao, W.; Guo, H.; Zhang, J.; Hu, G.; Yao, Y.; Dong, J. Hydrogen Peroxide is Involved in Salicylic Acid-Elicited Rosmarinic Acid Production in Salvia miltiorrhiza Cell Cultures. Sci. World J. 2014, 2014, 1-7. [CrossRef]

9. Alali, A.A.; Awad, M.A.; Al-Qurashi, A.D.; Mohamed, S.A. Postharvest gum Arabic and salicylic acid dipping affect quality and biochemical changes of 'Grand Nain' bananas during shelf life. Scient. Hortic. 2018, 237, 51-58. [CrossRef]

10. Mendoza, D.; Cuaspud, O.; Arias, J.P.; Ruiz, O.; Arias, M. Effect of salicylic acid and methyl jasmonate in the production of phenolic compounds in plant cell suspension cultures of Thevetia peruviana. Biotech. Rep. 2018, 19, e00273. [CrossRef]

11. Biruete-Guzmán, A.; Juárez-Hernández, E.; Sieiro-Ortega, E.; Romero-Viruegas, R.; Silencio-Barrita, J.L. Los nutracéuticos. Lo que es conveniente saber. Rev. Mex. Pediat. 2009, 76, 136-145.

12. Calderon-Montano, J.M.; Burgos-Morón, E.; Pérez-Guerrero, C.; López-Lázaro, M. A review on the dietary flavonoid kaempferol. Mini-Rev. Med. Chem. 2011, 11, 298-344. [CrossRef] [PubMed]

13. Vicente, O.; Boscaiu, M. Flavonoids: Antioxidant compounds for plant defence... and for a healthy human diet. Not. Bot. Horti Agrobot. Cluj-Napoca 2018, 46, 14-21. [CrossRef]

14. Gunes, A.; Inal, A.; Alpaslan, M.; Eraslan, F.; Bagci, E.G.; Cicek, N. Salicylic acid induced changes on some physiological parameters symptomatic for oxidative stress and mineral nutrition in maize (Zea mays L.) grown under salinity. J. Plant. Physiol. 2007, 164, 728-736. [CrossRef]

15. Rivas-San Vicente, M.; Plasencia, J. Salicylic acid beyond defense: Its role in plant growth and development. J. Exp. Bot. 2011, 62, 3321-3338. [CrossRef]

16. Steiner, A.A. A universal method for preparing nutrient solutions of a certain desired composition. Plant. Soil 1961, 15, 134-154. [CrossRef] 
17. Singleton, V.L.; Orthofer, R.; Lamuela-Raventós, R.M. Analysis of total phenols and other oxidation substrates and antioxidants by means of folin-ciocalteu reagent. Meth. Enzymol. 1999, 299, 152-178. [CrossRef]

18. Zhishen, J.; Mengcheng, T.; Jianming, W. The determination of flavonoid contents in mulberry and their scavenging effects on superoxide radicals. Food Chem. 1999, 64, 555-559. [CrossRef]

19. Hsu, C.-L.; Chen, W.; Weng, Y.-M.; Tseng, C.-Y. Chemical composition, physical properties, and antioxidant activities of yam flours as affected by different drying methods. Food chem. 2003, 83, 85-92. [CrossRef]

20. Fish, W.W.; Perkins-Veazie, P.; Collins, J.K. A quantitative assay for lycopene that utilizes reduced volumes of organic solvents. J. Food Comp. Anal. 2002, 15, 309-317. [CrossRef]

21. Padayatt, S.J.; Daruwala, R.; Wang, Y.; Eck, P.K.; Song, J.; Koh, W.S.; Levine, M. Vitamin C: From molecular actions to optimum intake. In Handbook of Antioxidants, 2nd ed.; Cadenas, E., Packer, L., Eds.; CRC press: Washington DC, USA, 2001; pp. 117-145. Available online: https://books.google.com.mx/books?id= Oq2WyueoZwIC\&pg=PA117\&dq=Vitamin+C: + from+molecular+actions+to+optimum+intake.\&hl=es419\&sa=X\&ved=2ahUKEwjsw_G6847sAhXPsZ4KHcdUD5cQ6AEwAHoECAMQAg\#v=onepage\&q= Vitamin\%20C\%3A\%20from\%20molecular\%20actions\%20to\%20optimum\%20intake.\&f=false (accessed on 31 July 2020).

22. SAS Version 9.3, SAS Institute: Cary, NC, USA. 2010. Available online: http://support.sas.com/software/93/ (accessed on 3 August 2020).

23. Steel, R.G.D.; Torrie, J.H. Principles and Procedures of Statistics. (With special Reference to the Biological Sciences); McGraw-Hill Book Company: New York, NY, USA, 1962. [CrossRef]

24. Basit, A.; Shah, K.; Rahman, M.U.; Xing, L.; Zuo, X.; Han, M.; Alam, N.; Khan, F.; Ahme, I.; Khalid, M.A. Salicylic acid an emerging growth and flower inducing hormone in marigold (Tagetes sp. L.). Pure. Appl. Biol. 2018, 7, 1301-1308. [CrossRef]

25. Moggia, C.; Graell, J.; Lara, I.; González, G.; Lobos, G.A. Firmness at harvest impacts postharvest fruit softening and internal browning development in mechanically damaged and non-damaged highbush blueberries (Vaccinium corymbosum L.). Front. Plant. Sci. 2017, 8, 535. [CrossRef] [PubMed]

26. Islam, M.Z.; Mele, M.A.; Choi, K.-Y.; Baek, J.P.; Kang, H. Salicylic acid in nutrient solution influence the fruit quality and shelf life of cherry tomato grown in hydroponics. Sains Malays. 2018, 47, 537-542. [CrossRef]

27. Shafiee, M.; Taghavi, T.; Babalar, M. Addition of salicylic acid to nutrient solution combined with postharvest treatments (hot water, salicylic acid, and calcium dipping) improved postharvest fruit quality of strawberry. Scient. Hortic. 2010, 124, 40-45. [CrossRef]

28. Boyero-Polo, L.; Juanes-Fernández, L.; Preciado-Riesco, A.; Sánchez-Tello, D.; Fathallah, O.; Núñez-Calvo, R.; Salamanca-Núñez, C.; Gallego-Nogueras, P. Contenido de vitamina C y azúcar en zumo de naranja y derivados industriales. Meridies 2019, 22, 33-38.

29. Baninaiem, E.; Mirzaaliandastjerdi, A.; Rastegar, S.; Abbaszade, K. Effect of pre- and postharvest salicylic acid treatment on quality characteristics of tomato during cold storage. Adv. Hort. Sci. 2016, 30, 183-192. [CrossRef]

30. De la Rosa, L.A.; Moreno-Escamilla, J.O.; Rodrigo-García, J.; Alvarez-Parrilla, E. Phenolic Compounds. In Postharvest Physiology and Biochemistry of Fruits and Vegetables; Elsevier Inc.: Amsterdam, The Netherlands, 2019; pp. 253-271. [CrossRef]

31. González-Paramás, A.M.; Ayuda-Durán, B.; Martínez, S.; González-Manzano, S.; Santos-Buelga, C. The Mechanisms Behind the Biological Activity of Flavonoids. Curr. Med. Chem. 2019, 26, 6976-6990. [CrossRef] [PubMed]

32. Suleman, M.; Khan, A.; Baqi, A.; Kakar, M.S.; Ayub, M. 2. Antioxidants, its role in preventing free radicals and infectious diseases in human body. Pure. Appl. Biol. 2019, 8, 380-388. [CrossRef]

33. Kumar, N.; Tokas, J.; Kumar, P.; Singal, H.R. Effect of salicylic acid on post-harvest quality of tomato (Solanum lycopersicum L.) fruit. Int. J. Chem. Stud. 2018, 6, 1744-1747.

34. Ghadage, S.R.; Mane, K.A.; Agrawal, R.S.; Pawar, V.N. Tomato lycopene: Potential health benefits. Pharma Innov. J. 2019, 8, 1245-1248.

35. Kant, K.; Arora, A.; Singh, V.P. Salicylic acid influences biochemical characteristics of harvested tomato (Solanum lycopersicon L.) during ripening. Ind. J. Plant. Physiol. 2016, 21, 50-55. [CrossRef] 
36. Yactayo-Chang, J.P.; Acosta-Gamboa, L.M.; Nepal, N.; Lorence, A. The Role of Plant High-Throughput Phenotyping in the Characterization of the Response of High Ascorbate Plants to Abiotic Stresses. In Ascorbic Acid in Plant Growth, Development and Stress Tolerance; Hossain, M., Munné-Bosch, S., Burritt, D., Diaz-Vivancos, P., Packer, L., Fujita, M., Lorence, A., Eds.; Springer: Cham, Switzerland, 2017; pp. 321-354. [CrossRef]

37. Wang, Y.; Chen, S.; Yu, O. Metabolic engineering of flavonoids in plants and microorganisms. Appl. Microbiol. Biotech. 2011, 91, 949-956. [CrossRef] [PubMed]

38. Askari, E.; Ehsanzadeh, P. Effectiveness of exogenous salicylic acid on root and shoot growth attributes, productivity, and water use efficiency of waterdeprived fennel genotypes. Hortic. Environ. Biotechnol. 2015, 56, 687. [CrossRef]

39. El Tayeb, M.A.; Ahmed, N.L. Response of wheat cultivars to drought and salicylic acid. Am. Euras. J. Agron. 2010, 3, 1-7.

40. Vázquez-Díaz, D.A.; Salas-Pérez, L.; Preciado-Rangel, P.; Segura-Castruita, M.Á.; González-Fuentes, J.A.; Valenzuela-García, J.R. Efecto del ácido salicílico en la producción y calidad nutracéutica de frutos de tomate. Rev. Mex. Cienc. Agríc. 2016, 17, 3405-3414.

41. Hayat, Q.; Hayat, S.; Irfan, M.; Ahmad, A. Effect of exogenous salicylic acid under changing environment: A review. Env. Experim. Bot. 2010, 68, 14-25. [CrossRef]

42. Larqué-Saavedra, A.; Martín-Mex, R.; Nexticapan-Garcéz, Á.; Vergara-Yoisura, S.; Gutiérrez-Rendón, M. Efecto del ácido salicílico en el crecimiento de plántulas de tomate (Lycopersicon esculentum Mill.). Rev. Chap. Ser. Hortic. 2010, 16, 183-187.

43. Terry-Alfonso, E.; Ruiz-Padron, J.; Carillo-Sosa, Y. Efecto de diferentes manejos nutricionales sobre el rendimiento y calidad de frutos de tomate. Agron. Mesoam. 2018, 29, 389-401. [CrossRef]

44. Sahu, R.K.; Agrawal, A.K.; Sinha, G. Extension of Shelf Life of Custard Apple (Annona squamosa L.) Through Post Harvest Treatments. Madr. Agric. J. 2016, 103, 62-66.

45. Youssef, R.A.; El-Azab, M.E.; Mahdy, H.A.; Essa, E.M.; Mohammed, K.A. Effect of salicylic acid on growth, yield, nutritional status and physiological properties of sunflower plant under salinity stress. Int. J. Pharm. Phytoph. Res. 2017, 7, 54-58.

46. Aghdam, M.S.; Asghari, M.; Farmani, B.; Mohayeji, M.; Moradbeygi, H. Impact of postharvest brassinosteroids treatment on PAL activity in tomato fruit in response to chilling stress. Scient. Hortic. 2012, 144, 116-120. [CrossRef]

47. Ezzat, A.; Ammar, A.; Szabó, Z.; Holb, I. Salicylic acid treatment saves quality and enhances antioxidant properties of apricot fruit. Hort. Sci. 2017, 44, 73-81. [CrossRef]

48. Swallah, M.S.; Sun, H.; Affoh, R.; Fu, H.; Yu, H. Antioxidant Potential Overviews of Secondary Metabolites (polyphenols) in Fruits. Int. J. Food Sci. 2020, 2020, 1-8. [CrossRef] [PubMed]

49. Hafeznia, M.; Mashayekhi, K.; Ghaderifar, F.; Mousavizadeh, S.J. Tomato morphological and biochemical characteristics in response to foliar applying of salicylic acid. Int. J. Biosci. 2014, 5, 237-243. [CrossRef]

50. Sariñana-Aldaco, O.; Sanchez-Chavez, E.; Fortis-Hernández, M.; González-Fuentes, J.A.; Moreno-Resendez, A.; Rojas-Duarte, A.; Preciado-Rangel, P. Improvement of the nutraceutical quality and yield of tomato by application of salicylic acid. Not. Bot. Horti Agrobot. Cluj-Napoca 2020, 48, 882-892. [CrossRef]

51. Fenech, M.; Amaya, I.; Valpuesta, V.; Botella, M.A. Vitamin C content in fruits: Biosynthesis and regulation. Front. Plant. Sci. 2019, 9, 2006. [CrossRef] [PubMed]

Publisher's Note: MDPI stays neutral with regard to jurisdictional claims in published maps and institutional affiliations.

(C) 2020 by the authors. Licensee MDPI, Basel, Switzerland. This article is an open access article distributed under the terms and conditions of the Creative Commons Attribution (CC BY) license (http://creativecommons.org/licenses/by/4.0/). 